\title{
PENGGUNAAN CABRI 3D TERHADAP PENINGKATAN KEMAMPUAN REPRESENTASI MATEMATIS SISWA
}

\author{
Rezkiyana Hikmah ${ }^{1}$, Sri Rezeki ${ }^{2}$, Bayu Jaya Tama ${ }^{3}$ \\ Program Studi Informatika, Universitas Indraprasta PGRI ${ }^{1,2,3}$ \\ Email: rezkiyana.hikmah2706@gmail.com ${ }^{1}$
}

\begin{abstract}
Abstrak
Penelitian ini dilakukan untuk menelaah kemampuan representasi matematis siswa yang belajar dengan media Cabri 3D dan siswa yang belajar dengan pembelajaran biasa (tidak menggunakan media Cabri 3D). Penelitian ini termasuk penelitian kuasi eksperimen. Sampel penelitian adalah siswa kelas VIII SMPN 1 di Cibinong. Instrumen penelitian yang digunakan adalah pretes dan postes. Pretes dan postes merupakan soal yang sama dan digunakan sebanyak dua kali yaitu di awal pertemuan dan di akhir pertemuan. Data penelitian dianalisis dengan menggunakan uji Mann Whitney dan uji $t$. Hasil penelitian ini menunjukkan bahwa peningkatan kemampuan representasi matematis siswa yang belajar dengan software Cabri 3D lebih baik daripada siswa yang belajar dengan pembelajaran biasa.
\end{abstract}

Kata Kunci : Media Cabri 3D, Kemampuan Representasi Matematis

\begin{abstract}
This reserch was condected to examine the mathematical representation ability of students who study with $3 D$ cabry media and students who study with ordinary learning (not using $3 D$ cabry media). This research is a quasi-experimental research. The sample of this research is grade VIII students of SMPN 1 in Cibinong. The research instruments used were pretest and posttest. Pretest and posttest are the same problem and are used as many times as at the beginning of the meeting and at the end of the meeting. The research data were analyzed using the mann whitney test and t test. The results of this study indicate that an increase in the mathematical representation ability of students who study with $3 D$ cabry software is better than students who study with ordinary learning.
\end{abstract}

Keywords : 3D Cabry Media,Mathematical Representation Ability

\section{PENDAHULUAN}

Pesatnya perkembangan media pembelajaran matematika saat ini ditandai dengan penggunaaan teknologi oleh guru dalam pembelajaran di kelas. Sekolah memfasilitasi komputer, laptop dan LCD serta infokus dalam meningkatkan kualitas sumber daya guru dan tujuan pembelajaran di kelas. Guru dituntut untuk mampu menggunakan fasilitas yang sudah disediakan oleh sekolah untuk meningkatkan kualitas kompetensi guru tersebut maupun kualitas dalam pembelajaran di kelas. Guru diharuskan mampu menyajikan bahan materi menggunakan media pembelajaran yang berbasis teknologi, seperti penggunaan software pembelajaran. Selain itu, guru juga dituntut mampu menggunakan teknologi komputer atau laptop dalam mengolah nilai, menyiapkan bahan ajar dan membuat assesmen soal. Matematika merupakan salah satu pelajaran yang tidak terlepas dari penggunaan gambar bangun datar 2D dan bangun ruang 3D.

Matematika juga identik dengan pembelajaran yang banyak berkenaan dengan angka-angka dan soal cerita. Hal tersebut sering menjadikan matematika sebagai mata pelajaran yang ditakuti dan dihindari oleh siswa. Selain materi yang dianggap rumit, pembelajaran matematika juga dianggap monoton dengan penggunaan papan tulis dan buku cetak matematika. Matematika identik dengan pelajaran yang disebut abstrak. Hal tersebut dikarenakan materi matematika mengikutsertakan daya imajinasi siswa dalam belajar, khususnya materi bangun ruang 3D. Oleh karena itu, banyak siswa 
yang kurang tertarik dan bahkan menganggap matematika itu sulit.

Persoalan tersebut dapat diatasi dengan menggunakan media pembelajaran inovatif yang berbasis teknologi informasi seperti penggunaan software pembelajaran matematika. Salah satu software yang dapat digunakan dalam pembelajaran bangun ruang adalah software Cabri 3D. Software Cabri 3D memiliki beberapa tools untuk mendesain pembelajaran matematika bangun ruang 3D agar lebih menarik. Selain itu, kesulitan siswa dalam melakukan imajinasi terhadap konsep bangun ruang dapat digiring ke dalam satu pemahaman yang sama, sehingga siswa tidak mengalami gagal paham dengan konsep materi.

Penggunaan software Cabri 3D dapat membantu siswa dalam memahami konsep sifat dari setiap bangun ruang yang akan dibahas melalui gambar yang jelas, sehingga siswa dapat memahami konsep tersebut. Contoh sederhana adalah ketika guru hendak menjelaskan bahwa sebuah kubus akan dibuka sehingga akan berubah menjadi sebuah jaring-jaring kubus. Pada saat menjelaskan konsep tersebut, guru biasanya menggunakan media kubus yang terbuat dari karton.

Selanjutnya, guru memotong sisi atas kubus dan sisi lainnya sehingga terbentuklah jaring kubus. Metode tersebut sudah jarang digunakan oleh guru lagi karena tidak efisien waktu. Oleh karena itu, beberapa guru terkadang meminta siswa untuk membayangkan sebuah kubus yang dibuka dari sisi atas kubusnya. Hal tersebut membuat beberapa siswa yang bingung dengan pernyataan yang dikemukakan oleh guru. Oleh karena itu, siswa mengalami kesulitan dalam memahami konsep sifat dari setiap bangun ruang.

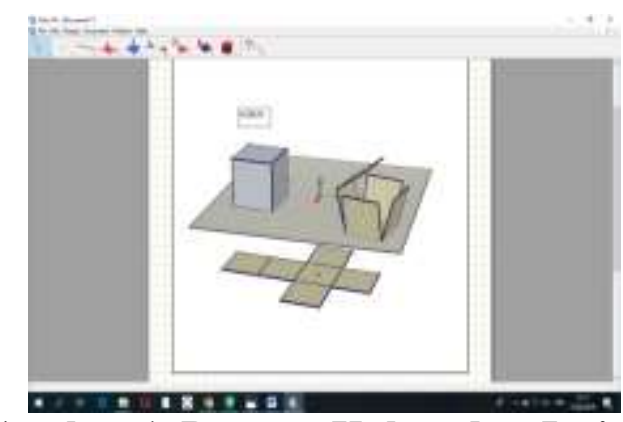

Gambar 1. Bangun Kubus dan JaringJaring Kubus

Berdasarkan gambar di atas, guru dapat mengkomunikasikan materi matematika dengan menggiring siswa dengan satu representasi gambar yang jelas dengan bantuan media. Siswa dapat melihat dengan jelas gambar yang disajikan tersebut. Oleh karena itu, guru tidak perlu meminta siswa untuk membayangkan bangun kubus ketika dibuka dari sisi atas. Penggunaan media pembelajaran yang tepat, akan memunculkan kemampuan siswa dalam merepresentasi gambar yang disajikan oleh media. Melalui gambar di atas, siswa dapat melihat bahwa kubus tersebut terdiri dari enam buah persegi yang kongruen dan sama. Siswa dapat mengemukakan sifat dari bangun kubus berdasarkan representasi yang disajikan melalui media gambar yang jelas dan menarik. Oleh karena itu, software Cabri 3D dapat membantu guru dalam memunculkan kemampuan representasi siswa dalam pembelajaran bangun ruang.

Tujuan dari penelitian ini adalah untuk mengetahui: (1) Kemampuan representasi matematis siswa yang belajar bangun ruang dengan pembelajaran Cabri 3D lebih baik daripada siswa yang belajar bangun ruang dengan pembelajaran biasa. (2) Peningkatan kemampuan representasi matematis siswa yang belajar bangun ruang dengan pembelajaran Cabri 3D lebih baik daripada siswa yang belajar bangun ruang dengan pembelajaran biasa. 
Selanjutnya, manfaat penelitian ini bagi penulis, siswa, dan guru adalah sebagai berikut.

1. Penulis

Menambah wawasan dan pengetahuan dalam melaksanakan penelitian dengan menggunakan Cabri 3D.

2. Siswa
a. Memperoleh pengalaman baru dalam pembelajaran menggunakan media Cabri 3D.
b. Siswa lebih tertarik dan termotivasi dalam pembelajaran matematika.
c. Meningkatkan kemampuan pemahaman dan representasi matematis siswa.

3. Guru
a. Sebagai acuan dalam mendesain pembelajaran yang lebih inovatif dan beragam.
b. Sebagai pengalaman dan menambah wawasan dalam menggunakan media Cabri 3D.
c. Membantu dalam pencapaian tujuan pembelajaran agar lebih maksimal.

Kemampuan representasi matematis merupakan kemampuan siswa dalam mengemukakan ide-ide, menggambarkan suatu situasi dalam bentuk gambar dan simbol matematika dalam menyelesaikan suatu permasalahan. The term representation refers both to process and to product; in other words, to the act of capturing a mathematical concept or relationship in some form and to the form itself. Moreover, the term applies to processes and products that are observable externally as well as to those that occur 'internally', in the minds of people doing mathematics [1]. Repesentasi mengartikan sebuah hubungan antara objek dan simbol. Representasi yang digunakan dalam pendidikan matematika dibagi dalam lima jenis, meliputi representasi obyek dunia nyata, representasi konkret, representasi simbol aritmetika, representasi bahasa lisan atau verbal dan representasi gambar atau grafik [2]. Lebih lanjut, di antara kelima representasi tersebut, tiga yang terakhir lebih abstrak dan merupakan tingkat representasi yang lebih tinggi dalam memecahkan masalah matematis:

a. Kemampuan representasi bahasa atau verbal adalah kemampuan menerjemahkan sifat-sifat yang diselidiki dan hubungan dalam masalah matematis ke dalam verbal atau bahasa.

b. Kemampuan representasi gambar atau grafik adalah kemampuan menerjemahkan masalah matematis ke dalam gambar atau grafik.

c. Kemampuan representasi simbol aritmetika adalah kemampuan menerjemahkan masalah matematis ke dalam representasi rumus aritmatika.

Representasi sebenarnya bukan menunjukkan kepada hasil atau produk yang diwujudkan dalam konfigurasi atau konstruk baru dan berbeda, tetapi proses berpikir yang dilakukan untuk dapat mengungkap dan memahami konsep, operasi, dan hubungan-hubungan matematik dari suatu konfigurasi [3]. Jadi, dengan kata lain proses representasi ini tidak hanya dalam bentuk eksternal saja, tetapi juga dalam bentuk internalnya. Memahami konsep matematika yang lebih penting bukanlah penyimpanan pengalaman masa lalu, tetapi bagaimana mendapatkan kembali pengetahuan yang telah disimpan dalam ingatan dan relevan dengan kebutuhan serta dapat digunakan ketika diperlukan [3].

Proses mendapatkan pengetahuan yang relevan dan penggunaannya sangat terkait dengan pengkodean pengalaman masa lalu tersebut. Proses tersebut merupakan aktivitas mental, yang oleh karenanya disebut representasi internal. Berbeda dengan representasi internal, representasi eksternal lebih mengacu pada perwujudan dari pemikiran dari siswa tersebut, seperti mengeluarkan gagasan atau ide dan 
merepresentasikan suatu permasalahan dalam bentuk gambar atau simbol-simbol matematika.
Secara umum bentuk representasi yang mungkin dibangun dari suatu masalah dapat dilihat pada Tabel 1 berikut.

\section{Tabel 1. Bentuk Representasi}

\begin{tabular}{|c|c|}
\hline Representasi & Bentuk Operasional \\
\hline $\begin{array}{l}\text { Visual dalam bentuk: } \\
\text { a. Gambar }\end{array}$ & $\begin{array}{l}\text { 1. Menyajikan kembali data atau informasi dari representasi ke } \\
\text { dalam bentuk tabel, diagram, grafik, dll. }\end{array}$ \\
\hline b. Tabel & $\begin{array}{l}\text { 2. Menggunakan representasi visual. } \\
\text { 3. Membuat gambar pola geometri. } \\
\text { 4. Memperjelas bangun geometri. }\end{array}$ \\
\hline $\begin{array}{l}\text { Ekspresi matematika atau } \\
\text { persamaan matematika }\end{array}$ & $\begin{array}{l}\text { 1. Membuat persamaan matematika atau model matematika dari } \\
\text { representasi ke representasi lain. }\end{array}$ \\
\hline \multirow{5}{*}{ Deskripsi atau pernyataan } & 2. Membuat konjektur dari pola yang ditemukan. \\
\hline & 3. Menyelesaikan masalah melalui persamaan matematika. \\
\hline & $\begin{array}{l}\text { 1. Membuat persamaan matematika atau model matematika dari } \\
\text { representasi ke representasi lain. }\end{array}$ \\
\hline & Membuat konjektur dari pola yang ditemukan. \\
\hline & 3. Menyelesaikan masalah melalui persamaan matematika. \\
\hline
\end{tabular}

Berdasarkan bentuk umum representasi, maka peneliti mengambil representasi visual. Sedangkan indikator dari representasi matematis pada penelitian relevan yakni dapat menerjemahkan masalah matematika ke dalam bentuk representasi gambar; simbol aritmetika; dan tabel [4].

Salah satu cara yang efektif dalam memecahkan persoalan matematika yaitu dengan menggunakan teknologi [5]. Melalui teknologi pembelajaran yang salah satunya dapat digunakan dalam matematika adalah software Cabri 3D. Software Cabri 3D merupakan aplikasi matematika yang dinamis dalam meyelesaikan geometri ruang. Software Cabri 3D merupakan pengembangan dari software Cabri II Plus. Cabri 3D adalah software yang sangat berguna untuk mengajar geometri tiga dimensi [6]. Software ini bersifat dinamis dari diagram digital yang membantu siswa dalam mengembangkan konsep geometri. Software Cabri 3D membantu siswa dalam mengkonstruksi bangun ruang dengan langkah-langkah konstruksi yang telah disiapkan. Software ini sangat membantu dan mempermudah dalam menyelesaikan permasalahan dalam matematika. Cabri 3D dapat dimanfaatkan sebagai media pembelajaran matematika untuk mendemonstrasikan atau memvisualisasikan konsep-konsep matematis serta sebagai alat bantu untuk mengkonstruksi konsep-konsep matematis [7].

\section{METODE}

Penelitian ini merupakan penelitian eksperimen semu. Sampel penelitian menggunakan keadaan sampel apa adanya. Hal tersebut bermakna bahwa peneliti tidak membuat kelas baru dengan melakukan pengambilan siswa secara acak dari kelas VIII SMPN 1 di Cibinong. Desain penelitian yang digunakan adalah desain kelompok kontrol non ekuivalen [8], sebagai berikut.

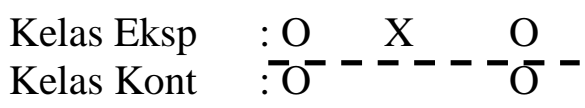

Keterangan:

$\mathrm{O}:$ Pretes atau Postes

$\mathrm{X}$ : Pembelajaran dengan Cabri 3D

-- : Subyek tidak diperoleh secara acak 
Penelitian ini menggunakan instrumen tes kemampuan representasi matematis pada masing-masing kelas (eksperimen dan kontrol) berupa tes awal (pretest) dan tes akhir (postest) dengan soal yang sama. Pemberian soal yang sama ini dilakukan untuk melihat ada atau tidaknya peningkatan akibat perlakuan sehingga akan lebih baik jika diukur dengan soal yang sama. Variabel penelitian ini terdiri dari pembelajaran dengan Cabri 3D dan pembelajaran biasa sebagai variabel bebas sedangkan kemampuan representasi matematis siswa sebagai variabel terikat. Populasi adalah seluruh siswa semester 2 pada salah satu SMPN di Cibinong, Tahun Pelajaran 2018/2019 dengan materi "Bangun Ruang Sisi Datar". Sampel penelitian adalah siswa kelas VIII SMPN Cibinong yang memiliki kemampuan heterogen.

Teknik pengambilan sampel adalah purposive sampling. Kelas yang dipilih sebagai sampel penelitian adalah VIIIA dan VIIIC. Kedua kelas tersebut dipilih dengan pertimbangan dan saran dari guru matematika yang mengajar kedua kelas tersebut bahwa kedua kelas memiliki kemampuan yang sama dalam matematika. Instrumen yang digunakan untuk mendapatkan data pada penelitian ini yaitu tes. Instrumen tes tersebut meliputi soalsoal yang digunakan untuk mengukur kemampuan representasi matematis siswa yang belajar di kelas eksperimen dan kelas kontrol.

Tes kemampuan representasi matematis pada penelitian ini disusun dalam bentuk tes uraian. Tes ini disusun dan dibuat sedemikian rupa sehingga tes ini mampu untuk mengukur kemampuan pemahaman dan representasi matematis pada siswa kelas VIII mengenai materi yang telah dipelajari. Indikator dan kriteria pemberian skor pada soal kemampuan representasi matematis dapat dilihat pada Tabel 2 berikut.

Tabel 2. Indikator Kemampuan Representasi Matematis

\begin{tabular}{|c|c|c|c|}
\hline Representasi & Indikator & Respon siswa & Skor \\
\hline \multirow{4}{*}{$\begin{array}{l}\text { Visual dalam } \\
\text { bentuk gambar }\end{array}$} & Menyajikan & Tidak menjawab & 0 \\
\hline & $\begin{array}{l}\text { kembali data atau } \\
\text { informasi dari }\end{array}$ & $\begin{array}{l}\text { Melukiskan, diagram, gambar, namun } \\
\text { penjelasan kurang. }\end{array}$ & 1 \\
\hline & $\begin{array}{l}\text { representasi ke } \\
\text { dalam bentuk }\end{array}$ & $\begin{array}{l}\text { Melukiskan, diagram, gambar, namun kurang } \\
\text { lengkap dan benar. }\end{array}$ & 2 \\
\hline & $\begin{array}{l}\text { gambar pola } \\
\text { geometri }\end{array}$ & $\begin{array}{l}\text { Melukiskan, diagram, gambar, secara lengkap } \\
\text { dan benar. }\end{array}$ & 3 \\
\hline
\end{tabular}

Soal tes kemampuan representasi ini diujicobakan pada siswa kelas IX di SMPN 1 Cibinong. Uji coba ini dilaksanakan pada hari Senin tanggal 25 Februari 2019 dengan jumlah butir soal 9 yaitu 5 butir soal pemahaman dan 4 butir soal representasi dengan waktu 90 menit.

\section{HASIL DAN PEMBAHASAN}

Berdasarkan hasil pengujian nilai signifikan dari pretes di kelas eksperimen dan kelas kontrol masing-masing adalah
0,001 dan 0,000. Hal tersebut menunjukkan bahwa nilai signifikan untuk pretes kelas eksperimen lebih rendah dari $\alpha=0,05$, yang berarti $H_{0}$ ditolak. Sedangkan nilai signifikan di kelas kontrol juga lebih rendah dari $\alpha=0,05$, yang berarti $H_{0}$ diterima. Oleh karena itu, data tidak berdistribusi normal. Nilai signifikan dari postes di kelas eksperimen dan kelas kontrol masing-masing adalah 0,200 dan 0,200 . Hal tersebut menunjukkan bahwa nilai signifikan untuk postes kelas 
eksperimen lebih tinggi dari $\alpha=0,05$, yang berarti $H_{0}$ diterima. Sedangkan nilai signifikan di kelas kontrol juga lebih tinggi dari $\alpha=0,05$, yang berarti $H_{0}$ diterima. Oleh karena itu, data berdistribusi normal. Nilai signifikan dari n-gain di kelas eksperimen dan kelas kontrol masingmasing adalah 0,200 dan 0,138. Hal tersebut menunjukkan bahwa nilai signifikan untuk $n$-gain kelas eksperimen dan kontrol lebih tinggi dari $\alpha=0,05$, yang berarti $H_{0}$ diterima. Oleh karena itu, data berdistribusi normal. Dengan demikian, data postes dan n-gain kemampuan representasi siswa dilanjutkan dengan uji homogen. Sedangkan data pretes kemampuan representasi siswa dilanjutkan dengan uji non-parametrik yaitu uji Mann-Whithney.

Berdasarkan hasil pengujian diperoleh bahwa nilai Levene's Sig postes dari hasil uji homogenitas varians adalah 0,017 . Hal tersebut menunjukkan bahwa nilai Levene's Sig lebih rendah dari nilai $\alpha=$ 0,05 sehingga varians skor postes di kelas eksperimen dan kontrol adalah tidak homogen. Oleh karena itu, dapat disimpulkan bahwa $H_{0}$ ditolak. Dengan demikian, data postes dilanjutkan dengan uji-t. Sedangkan nilai Levene's Sig. n-gain dari hasil uji homogenitas varians adalah 0,949. Hal tersebut menunjukkan bahwa nilai Levene's Sig lebih tinggi dari nilai $\alpha=0,05$, sehingga varians skor $n$-gain di kelas eksperimen dan kontrol adalah homogen. Oleh karena itu, dapat disimpulkan bahwa $H_{0}$ diterima. Dengan demikian, data $n$-gain dilanjutkan uji-t.

Berdasarkan hasil pengujian diperoleh bahwa nilai sig pretes kemampuan representasi matematis lebih tinggi dibanding dengan nilai $\alpha=0,05$ yang berarti $H_{0}$ diterima. Hal tersebut dapat diartikan bahwa kemampuan representasi matematis siswa dari kelas eksperimen dan kelas kontrol tidak terdapat perbedaan signifikan. Selanjutnya, untuk melihat adanya perbedaan atau tidak pada peningkatan kemampuan representasi matematis siswa maka digunakan data nilai postes atau $n$-gain.

Berdasarkan hasil uji perbedaan rerata diperoleh bahwa data nilai postes dilakukan dengan uji Mann-Whitney nilai signifikansi satu pihak pada nilai postes kemampuan representasi matematis lebih tinggi dari nilai $\alpha=0,05$ yaitu 0,053 maka $H_{0}$ diterima. Hal tersebut dapat diartikan bahwa kemampuan pemahaman matematis siswa yang belajar dengan software Cabri 3D tidak lebih baik daripada siswa yang belajar dengan pembelajaran biasa. Sedangkan nilai signifikansi satu pihak pada nilai $n$-gain kemampuan representasi matematis lebih rendah dari nilai $\alpha=0,05$ yaitu 0,000 maka $H_{0}$ ditolak. Hal tersebut dapat diartikan bahwa peningkatan kemampuan representasi matematis siswa yang belajar dengan software Cabri 3D lebih baik daripada siswa yang belajar dengan pembelajaran biasa. Peningkatan kemampuan representasi siswa yang terjadi cukup signifikan dengan kategori peningkatan yang rendah.

Hasil penelitian ini menunjukkan bahwa rerata skor pretest kemampuan representasi matematis siswa di kelas eksperimen dan kontrol masing-masing adalah 2,36 dan 2,76. Selisih rerata skor pretest kemampuan representasi matematis dari kedua kelas tersebut adalah 0,40. Dilihat dari persentase rerata skor pretest kemampuan representasi matematis siswa di kelas eksperimen dan kontrol adalah $15,73 \%$ dan $18,4 \%$. Selisih persentase rerata skor kemampuan representasi matematis dari kedua kelas adalah 2,67\%. Selisih dari kedua persentase rerata skor pretest kemampuan representasi matematis pada kedua kelas menunjukkan bahwa tidak terdapat perbedaan kemampuan awal 
representasi matematis siswa di kelas eksperimen maupun kelas kontrol. Hal ini diperkuat dengan hasil uji perbedaan dua rerata skor pretest yang menyatakan tidak terdapat perbedaan kemampuan awal representasi matematis siswa kelas eksperimen dan kelas kontrol.

Pretest diberikan kepada siswa dengan tujuan untuk mengetahui bagaimana kemampuan awal representasi matematis siswa di kelas eksperimen dan kontrol. Selanjutnya dilakukan posttest untuk mengetahui pencapaian siswa terhadap suatu materi yang dipengaruhi oleh pemberian perlakuan yang berbeda untuk masing-masing kelas yaitu menggunakan media Cabri 3D di kelas eksperimen dan pembelajaran biasa di kelas kontrol. Posttest diberikan setelah pembelajaran dilaksanakan selama 4 kali pertemuan.

Berdasarkan hasil analisis statistik deskriptif diperoleh rerata skor posttest kemampuan representasi matematis siswa di kelas eksperimen dan kontrol adalah 6,44 dan 5,04. Selisih rerata skor posttest dari kedua kelas tersebut adalah 1,40 yang berarti adanya perbedaan rerata skor posttest dari kedua kelas. Ditilik dari persentase rerata skor posttest kemampuan representasi dari masing-masing kelas eksperimen dan kontrol adalah $42,93 \%$ dan $33,60 \%$ dengan selisih persentase sebesar $9,33 \%$. Selisih persentase rerata skor posttest tersebut menunjukkan bahwa terdapat perbedaan pencapaian hasil rerata skor postest kemampuan representasi matematis siswa yang belajar dengan media Cabri 3D dan siswa yang belajar dengan pembelajaran biasa.

Selanjutnya hasil uji perbedaan dua rerata skor posttest kemampuan representasi juga menunjukkan bahwa pencapaian kemampuan representasi matematis siswa yang belajar dengan media Cabri 3D lebih baik daripada pembelajaran biasa.
Penelitian ini dilakukan dengan kondisi bahwa terdapat perbedaan kemampuan awal representasi matematis siswa di kelas eksperimen dan kelas kontrol sebelum pembelajaran materi "bangun ruang sisi datar" dilaksanakan. Bertolak dari kemampuan awal representasi matematis yang berbeda maka akan dilihat bagaimana peningkatan kemampuan representasi matematis siswa yang belajar dengan media Cabri 3D dan pembelajaran biasa dengan melihat hasil skor posttest dan $\mathrm{N}$ Gain. Skor N-Gain bertujuan untuk melihat seberapa besar peningkatan kemampuan representasi matematis siswa dengan membandingkan antara pencapaian skor pretest dan posttest. Pembandingan skor pretest dan posttest ini untuk melihat seberapa besar peningkatan yang dicapai oleh siswa yang belajar dengan media Cabri 3D di kelas eksperimen dan siswa yang belajar dengan pembelajaran biasa. Interpretasi untuk hasil perhitungan gain dapat diklasifikasikan sebagai berikut.

Tabel 3. Klasifikasi Gain Ternormalisasi

\begin{tabular}{cc}
\hline Besarnya Gain (g) & Klasifikasi \\
\hline $\mathrm{g} \geq 0,7$ & Tinggi \\
$0,3 \leq \mathrm{g}<0,7$ & Sedang \\
$\mathrm{g}<0,3$ & Rendah \\
\hline & \multicolumn{2}{c}{ Sumber: [10] }
\end{tabular}

Ditinjau dari rerata skor $N$-Gain kemampuan representasi matematis siswa di kelas eksperimen dan kontrol masingmasing adalah 0,31 dan 0,18 dengan kriteria rendah dengan selisih rerata skor $N$-Gain sebesar 0,13. Selisih ini menunjukkan bahwa terdapat perbedaan peningkatan kemampuan representasi matematis siswa yang belajar dengan media Cabri 3D dan pembelajaran biasa dengan kategori rendah. Hasil uji perbedaan dua rerata skor $N$-Gain yang dilakukan dengan uji- $t$ menunjukkan bahwa nilai sig (1-tailed) sebesar 0,000 < $\alpha=0,05$. Hal ini menjelaskan bahwa siswa yang belajar dengan media Cabri 3D memiliki peningkatan kemampuan 
representasi matematis yang lebih baik daripada siswa yang belajar dengan pembelajaran biasa.

Selanjutnya, jika dibandingkan dengan bahasan dari penelitian relevan menunjukkan bahwa kemampuan representasi yang dilihat bukan pada peningkatan kemampuan representasi $(\mathrm{N}$ Gain) sebelum dan setelah dilaksanakan pembelajaran di kelas. Namun, mengeksplor kemampuan representasi siswa berdasarkan strata sekolah (tinggi, sedang dan rendah) yang menunjukkan bahwa siswa dari sekolah starata tinggi lebih baik capaiannya dibanding dengan siswa dari sekolah stra sedang dan rendah[4].

\section{SIMPULAN}

Berdasarkan uraian dan penjelasan pada hasil penelitian dan pembahasan sebelumnya, kesimpulan penelitian yang dapat dikemukakan adalah.

1. Kemampuan representasi matematis siswa yang belajar dengan software Cabri 3D lebih baik daripada siswa yang belajar dengan pembelajaran biasa.

2. Peningkatan kemampuan representasi matematis siswa yang belajar dengan software Cabri 3D lebih baik daripada siswa yang belajar dengan pembelajaran biasa.

\section{DAFTAR PUSTAKA}

[1] N. C. T. Mathematics. Principle and Standarts for School. USA: NCTM, 2000.

[2] W. Y. Hwang, N. S. Chen, J. J. Dung, and Y. L. Yang. "Multiple representation skills and creativity effects on mathematical problem solving using a multimedia whiteboard system". Educ. Technol. Soc., vol. 10, no. 2, pp. 191-212,
2007.

[3] J. A. Dahlan. Analisis Kurikulum Matematika. Jakarta: Universitas Terbuka, 2011.

[4] A. Absorin dan S. Sugiman. "Eksplorasi Kemampuan Penalaran dan Representasi Matematis Siswa Sekolah Menengah Pertama”. PYTHAGORAS (Jurnal Pendidik. Mat., vol. 13, no. 2, pp. 189-202, 2018.

[5] I. Nuriadin. "Pembelajaran Kontekstual Berbantuan Program Geometer's Sketchpad dalam Meningkatkan Kemampuan Koneksi dan Komunikasi Matematis Siswa SMP”. Infin. J., vol. 4, no. 2, pp. 168-181, 2015.

[6] G. Accascina and E. Rogora. "Using Cabri3D Diagrams for Teaching Geometry". Int. J. Technol. Math. Educ., vol. 13, no. 1, pp. 11-22, 2006.

[7] B. Hendriana, I. Nuriadin, dan L. Rachmaeni3. "Pengaruh Model Brain-Based Learning Berbantu Cabri 3D terhadap Kemampuan Spasial Matematis Siswa". $J$. THEOREMS (The Orig. Res. Math., vol. 4, no. 1, pp. 18-28, 2019.

[8] Ruseffendi. Dasar-Dasar Penelitian Pendidikan dan Bidang NonEksakta Lainnya. Bandung: Tarsito, 2005.

[9] A. Irma. "Peningkatan Kemampuan Pemahaman dan Representasi Matematis Siswa Sekolah Menengah Atas melalui Strategi Think-Talk-Write". SPS UPI Bandung, 2011.

[10] R. R. Hake. "InteractiveEngagement vs Traditional Methods: A Six-Thousand-Student Survey of Mechanics Test Data for Introductory Physics Courses". Am. J. Phys., vol. 66, pp. 64-74, 1998. 